\title{
Investigation of MMP-9 and E-Selectine Levels in Gunshot Injuries
}

\section{Ateşli Silah Yaralanmalarında MMP-9 ve E-Selektin Düzeylerinin Araştırılması}

\author{
Elif Demir, @Ramazan Giden² \\ 'Harran University Medical School Department of Medical Biochemistry, Şanliurfa, Turkey \\ 2Sanliurfa Research and Training Hospital Emergency Department, Şanliurfa, Turkey
}

\begin{abstract}
Aim: Our aim in this study is to determine how matrix metalloproteinase-9 (MMP-9) and E-selectin levels are affected in the damage caused by gunshot injuries. At the same time, it is to investigate the value of these parameters in terms of biochemical parameters in these cases and to propose new opinions on the subject.

Material and Method: 40 control groups and 48 patients who were brought to the hospital emergency department as a result of gunshot wounds were included in the study. Venous blood samples of the patient and control groups were taken. Serum MMP-9 and E-selectin levels were measured quantitatively by using ELISA method. The obtained results were evaluated in the SPSS 25 program.

Results: MMP-9 levels measured in our patient group were significantly higher than in the control group $(p<0.001)$. Although the patient group was higher than the control group in terms of e-selectin levels, no statistical significance was found.

Conclusion: Various tissue damage occurred in the patient group. The release of MMP-9 by inflammatory cells indicates that serum MMP-9 levels are high in patients with intense inflammation and high inflammatory cell load. The increase in E-selectin level indicates endothelial cell damage.
\end{abstract}

Keywords: Gunshot, injury, MMP-9, E-selectin
Öz

Amaç: Bu çalışmadaki amacımız, ateşli silah yaralanmalarında meydana gelen hasarda matriks metaloproteaz-9 (MMP-9) ve E-selektin düzeylerinin nasıl etkilendiğini tespit etmek. Aynı zamanda bu parametrelerin bu vakalardaki biyokimyasal parametre açısından değerini araştırmak, konuyla ilgili yeni görüşler ileri sürebilmektir.

Gereç ve Yöntem: Ateşli silah yaralanmasına sonucu hastane acil servisine getirilen 48 olgu ile 40 kontrol grubu çalışmaya alındı. Hasta ve kontrol grubun venöz kan örnekleri alındı. Serum MMP-9 ve E-selektin düzeyleri ELISA yöntemi uygulanarak kantitatif olarak çalışıldı. Elde elden sonuçlar SPSS 25 programında değerlendirildi.

Bulgular: Hasta grubumuzda ölçülen MMP-9 düzeyleri kontrol grubuna göre anlamlı derecede yüksek iken $(p<0,001)$, E-selektin düzeyleri açısından hasta grubu, kontrol grubundan yüksek olmasın rağmen istatistiksel olarak herhangi bir anlamllık tespit edilmedi.

Sonuç: Hasta grubunda çeşitli doku hasarları meydana gelmiştir. MMP-9'un inflamatuvar hücrelerce salınması, inflamasyonun yoğun olduğu ve inflamatuvar hücre yükünün fazla olduğu hastalarda serum MMP-9 düzeylerinin yüksek olduğunu görülmüştür. E-selektin düzeyindeki bir miktar artış ise endotel hücre hasarını göstermektedir.

Anahtar Kelimeler: Ateşli silah, yaralanma, MMP-9, E-selektin 


\section{INTRODUCTION}

In recent years, with the increasing rate of wars, terrorist incidents and individual armament, the frequency of injuries caused by gunshot has been increasing. Gunshot injuries are a group of trauma with difficulties in their treatment and high morbidity and mortality rates. The most important reason for that bullets and explosive weapon parts carrying high kinetic energy that cause such injuries can damage the surrounding tissues due to the blast effect (temporary cavity) while moving through the body. ${ }^{[1,2]}$ In addition to the permanent and temporary cavity effects of high kinetic energy weapons, the damage they inflict increases with the effects of both the deflected bullet fragments and the bone tissues that they shred as they move through the body. For this reason, it is extremely difficult to predict the size of the actual injury and the complications that may develop in patients. ${ }^{[3]}$ The modern wound ballistics bullet or projectile on which Kocher is based; examines penetration (puncture], permanent cavity (wound path), temporary cavity (blast effect), fragmentation and shock waves effects. ${ }^{[4]}$ Penetration is the first and main effect of the bullet. The kinetic energy of a bullet determines the penetrating power. ${ }^{[5]}$ Bone, cartilage, tendon and other hard tissues to which kinetic energy is transferred can also act like bullets and cause damage. Physical penetration of the bullet through the tissues causes a permanent tissue loss or tissue destruction. ${ }^{[6,7]}$ When the bullet enters the body, it first encounters the skin tissue. Since the skin tissue is rich in elastic connective tissue, it shows a high resistance to penetration. Among the body tissues, the most resistant tissue against penetration is bone tissue. The organs that can cause death at first glance in the human body are protected with bones. ${ }^{[8]}$ Muscle tissue is moderately resistant to bullet penetration, however, it is the overlying fascia layer that increases the resistance of the muscle tissue. ${ }^{[9]}$ Hollow organs such as stomach and intestines show moderate resistance to bullets due to their wall structures. The factor determining the severity of the injury in hollow organs is the blast effect created by the bullet in the organ. Parenchymal organs such as the liver are extremely sensitive to penetration, and the bullet usually pierces these organs completely. ${ }^{[8]}$ One of the factors that change the severity, depth and size of the injury in penetrating traumas due to gunshot is the rupture of the bullet. Pistol bullets often deform when colliding with a hard obstacle, but rifle bullets can easily break up when colliding with a hard object. Bone tissue is the biggest factor causing bullet disintegration in body tissues. ${ }^{[10]}$

The extracellular matrix (EM) is a dynamic structure that creates a special environment in the intercellular spaces. It helps hold cells in tissues together and acts as a reservoir for many hormones that control cell growth and differentiation. Matrix metalloproteases (MMPs) are a multigenic family of endopeptidases that break down EM and are active at neutral Ph. ${ }^{[1]}$ Although MMP-9 breaks down EM, it proteolytically breaks down decorin, elastin, fibrilin, laminin, gelatin, and type IV, V, XI, and XVI collagen. MMP-9 plays a major role in normal tissue structuring such as axon development, embryonic development, angiogenesis, ovulation, mammary gland formation and wound healing. ${ }^{[12]}$ MMP-9 is frequently encountered in invasive and highly tumorigenic cancers such as colorectal tumors, gastric carcinoma, pancreatic carcinoma, breast and mouth cancer, melanoma, malignant glioma, chondrosarcoma, and gastrointestinal adenocarcinoma. ${ }^{[13]}$ Activation of MMP-9 has also been observed in diseases such as arthritis, autosomal recessive osteolysis disorder, coronary artery disease, emphysema and diabetic retinopathy. ${ }^{[14]}$

Selectins are multifunctional adhesion molecules that regulate the initial interactions between circulating leukocytes and endothelial cells. Adhesion molecules; they are involved in cell protection, wound healing, and tissue integrity. ${ }^{[15]}$ Leukocytes attach to the vascular wall in response to tissue damage or infection via 3 types of adhesion receptors called selectin. Selectins are expressed on the surface of endothelial cells, leukocytes, and platelets. ${ }^{[16]}$ Its expression increases against inflammatory stimuli. ${ }^{[17]}$ Selectins (P, E and L) and their ligands are required for leukocyte rolling and binding in the vascular wall. ${ }^{[18]}$ Circulating E-selectin (soluble) is accepted as a marker of endothelial cell damage or activation. ${ }^{[19]}$

\section{MATERIAL AND METHOD}

This study was approved by the Harran University Ethics Committee (no:2016/03-35). In this study, the necessary ethics committee approval was obtained and all participants included in the study were informed about what to do with the "Informed Consent Form" and their consent was obtained for their volunteerism.

Patient Group: Among the cases brought to the hospital emergency department as a result of Gunshot injuries, no additional pathology was found except for gunshot-related injuries and no systemic disease was detected in clinical and laboratory examinations, and those who did not use alcohol, cigarettes and drugs were included in our study. The age distribution of the cases, their characteristics such as the injured area and organs were determined and discussed. All 48 cases included in our study were male and the age range was between 18-51. The injuries were predominantly in the lower and upper extremities, but also in the chest, abdomen, thorax head and neck regions. All of our cases recovered and were discharged after the treatment they received.

Control Group: As the control group, 40 healthy adults with no history of complaints, no pathology detected in physical examination, no local or systemic disease detected in clinical and laboratory examinations, and no alcohol, smoking or drug use were included in the study. All of our control group was male and was in the age range suitable for the patient group.

Venous blood samples of the patients were collected. Centrifugation was done at 1000 rpm for 10 minutes. It was stored at -80 degrees until biochemical analysis. Serum MMP9 and E-selectin levels were measured quantitatively by using ELISA method. 


\section{Statistical Analysis}

While evaluating the study data, besides descriptive statistical methods (mean, standard deviation), the Independent simple $T$ test was used for the comparison of the parameters between the groups for the comparison of quantitative data. One-Way ANOVA test was used in group comparisons consisting of more than 2 groups. Pearson and Spearman's correlation analysis was used to evaluate the relationships between parameters within the group of parameters with normal distribution. Significance was evaluated at the $p<0.05$ level.

\section{RESULTS}

In gunshot injuries included in our study, the patient group and our control group were all male, and the average ages of the participants were consistent (Table 1).

$\begin{aligned} & \text { Table 1. Average age and standard deviation (SD) of the patient and } \\
& \text { control groups in gunshot injuries }\end{aligned}$
\begin{tabular}{lc} 
& Mean \pm SD \\
\hline Patient (48) & $27,79 \pm 10,54$ \\
Control (40) & $28,98 \pm 11,10$ \\
\hline
\end{tabular}

MMP-9, E-selectin levels and $P$ values measured in the patient group in our study and the control group are shown in Table 2. MMP-9 levels measured in our patient group were significantly higher than in the control group $(p<0.001)$. Although the patient group was higher than the control group in terms of e-selectin levels, no statistical significance was found. No significant positive or negative correlation was found between these parameters in the gunshot injured patient group.

\begin{tabular}{|c|c|c|c|}
\hline & Group & Mean \pm SD & $\mathbf{P}$ \\
\hline \multirow{2}{*}{ MMP-9 } & Patient & $1543.35 \pm 758.86$ & \multirow{2}{*}{$<0,001$} \\
\hline & Control & $903.27 \pm 323.65$ & \\
\hline \multirow{2}{*}{ E-Selectin } & Patient & $27.75 \pm 11.43$ & \multirow{2}{*}{0.489} \\
\hline & Control & $25.95 \pm 12.84$ & \\
\hline
\end{tabular}

\section{DISCUSSION}

Gunshot wounds are a group of trauma that has difficulties in treatment and has a high morbidity-mortality rate..$^{[20,21]}$ While the bullets traverse high-density tissues such as muscle, liver and spleen, a global destruction occurs in the tissues in front of them with the effect of a shock wave. With the effect of these shock waves, tissue damage may occur at a distant point other than where the bullet passes. ${ }^{[22,23]}$ There is no study in the literature showing the comparison of MMP-9 and E-selectin levels in gunshot injuries.
MMPs have been found to play a role in many diseases in studies conducted to date. MMPs were found to be associated with stroke, multiple sclerosis, Alzheimer's disease, cancer, atherosclerosis, arthritis, nephritis, gastrointestinal ulcer, periodontal disease, corneal ulcer, skin ulcer, liver fibrosis and pulmonary diseases such as asthma, emphysema, and chronic obstructive pulmonary disease. ${ }^{[24]}$

In the group of gelatinases are MMP 2 (gelatinase A) and MMP 9 (gelatinase B). This group easily digests denatured collagen and gelatin. ${ }^{[25]}$ Type IV collagen is the main component of basement membranes and constitutes $40-65 \%$ of the basement membrane total protein. ${ }^{[26]}$ MMP-9, whose primary task is to break down EM, also plays a major role in normal tissue reconstruction such as axon development, embryonic development, angiogenesis, ovulation, mammary gland formation and wound healing. ${ }^{[12]}$

Many studies have determined different serum MMP-9 levels. Cojocarui et al. ${ }^{[27]}$ found that MMP-9 level in the acute period in ischemic stroke. Eckart et al. ${ }^{[28]}$ found MMP-9 levels to be low in acute myocardial infarction and it was stated that this low MMP-9 level could be an indicator of myocardial damage. Susskind et al. In his study, lung damage caused by ionizing radiation was examined by looking at the plasma levels of MMP-9, TIMP-1 and MMP-3, which are biological markers of tissue damage, and their relationship with pulmonary epithelial permeability, clinical signs, symptoms, and structural changes in the lung. MMP-9, TIMP-1 and MMP-3 levels were measured before treatment, during treatment and approximately $100^{\text {th }}$ day after treatment in eight patients with breast and lung cancer who received radiotherapy to the chest region. In all of these patients, MMP-9 and TIMP-1 levels, which were very high before radiotherapy, were observed to have a sudden decrease only in MMP-9 after the first two weeks of radiotherapy. ${ }^{[29]}$

Inflammation is a protective response developed for the continuity of the organism to prevent microorganisms or toxins from damaging cells or to remove necrotic and dead tissues caused by damage. ${ }^{[30]}$ Under normal conditions, strict control of the response prevents further damage and while the damaged tissues are cleaned, pathological inflammation that occurs in disease states causes EM destruction and organ dysfunction. ${ }^{[31]}$ MMPs are secreted in response to a variety of inflammatory mediators and inhibited by tissue inhibitors of matrix metalloproteinases (TIMPs).

When the MMP-9 levels measured in the patient group and the control group were compared in gunshot injuries included in our study; The patient group was significantly higher than the control group $(p<0.001)$. Various tissue damage occurred in the patient group. The release of MMP-9 by inflammatory cells explains the high serum MMP-9 levels in patients with intense inflammation and high inflammatory cell load.

Adhesion molecules are involved in cell protection, wound healing, and tissue integrity. ${ }^{[32]}$ As is known, there are four types of adhesion molecule families. These are integrins, selectins, 
immunoglobins and cadherins. Selectins are expressed on the surface of endothelial cells, leukocytes, and platelets.[16] E-selectin mainly plays a role in leukocyte adhesion. The role of the e-select in this phenomenon is to ensure that the rolling returns to slow rolling and tight adhesion. It has been shown that antibodies that act directly against E-selectin prevent inflammation and thus, E-selectin is an adhesion molecule that plays a role in inflammation. ${ }^{[33]}$

In recent studies, it has been shown that inflammation has a share in many diseases and health problems and is associated with different clinical forms of these diseases. ${ }^{[34-38]}$ Adhesion molecules show endothelial activation or damage. Adhesion molecules stimulated by circulating cytokines direct the movement of cells instead of inflammation. ${ }^{[34]}$ Excessive proteolytic enzyme release due to inflammation disrupts the connection of these epithelial cells with each other and with EM. ${ }^{[38]}$ It is known that endothelial cells have many functions that regulate immune and inflammatory events. Cell adhesion molecules play a role in the leukocyte-endothelial relationship. ${ }^{[34]}$ The first step in the development of the inflammatory response is the adhesion of leukocytes to the vascular endothelium. E-selectin, one of the various adhesion molecules whose expression is known to be the result of cytokine activation, is the earliest released adhesion molecule. Studies show that the expression of E-selectin increases in the first two hours when the inflammatory response begins to ocur. ${ }^{[35]}$

When the E-selectin levels measured in the patient group and the control group were compared in the gunshot injuries included in our study, although the patient group was higher than the control group, no statistically significant significance was found $(p=0.489)$. However, the increase in the level of $\mathrm{E}$-selectin in the patient group compared to the control group indicates that there is endothelial cell damage.

\section{CONCLUSION}

Our aim in this study was to determine how MMP-9 and E-selectin levels are affected in gunshot injuries. These parameters are not routine laboratory parameters. Although patients with lower and upper extremity gunshot injuries are prominent, a small number of patients with injuries to other body parts were also included in our study. Although the number of patients with extra-extremity injuries in our study was low, MMP-9 levels increased statistically significantly in our patient group. All our patients were discharged after treatment without any complications. With this study, we think that $\mathrm{mmp}-9$ levels may be an important parameter in showing the level of tissue damage in this patient group. The significant increase in MMP-9 within hours in sudden situations such as gunshot injury suggests that it may be a routine parameter that can be used to monitor the increase or decrease of tissue damage in patient follow-up. Our study should be supported by comprehensive studies in order to get better and to reach more precise results results in terms of these parameters.

\section{ETHICAL DECLARATIONS}

Ethics Committee Approval: This study was approved by the Harran University Ethics Committee (no: 2016 / 03-35, date: 01.04.2016).

Informed Consent: All patients signed the free and informed consent form.

Referee Evaluation Process: Externally peer-reviewed.

Conflict of Interest Statement: The authors have no conflicts of interest to declare.

Financial Disclosure: This study was supported by Harran University Research Fund (Project Number: 16065).

Author Contributions: All of the authors declare that they have all participated in the design, execution, and analysis of the paper, and that they have approved the final version.

\section{REFERENCES}

1. Peters CE, Sebourn CL. Wound ballistics of unstable projectiles. Part II: temporary cavity formation and tissue damage. J Trauma 1996;40:S16-21.

2. Mesci A, Arıcı C. Travma kinematiği. Ulusal Cerrahi ve Travma Resüsitasyon Kurs Kitabı, 2008.

3. Uzar Al, Dakak M, Sağlam M, Ozer T, Ogunç G, Ide T, et al. The magazine: a major cause of bullet fragmentation. Mil Med 2003;168:969-74.

4. Fackler M.L., Wound Ballsitics. JAMA. 1998; 259(18): 2730-36.

5. Kara Kuvvetleri Komutanlığı Kara Harp Okulu Komutanlığı Silah sistemleri ve balistik ders kitabı, Ankara, 2006.

6. Di Maio VJM. Gunshot Wounds, practical Aspects of Firearms, Ballistics and forensic tecniques. 2nd Ed. CRC Press. LCL, 1999.

7. Kar H. Ateşli Silah Yaralarında Karboksihemoglobin Analizi. Uzmanlık Tezi. Adli Tıp Kurumu. İstanbul, 2002.

8. Barach E, Tomlanovich M, Nowak R. Ballistics: A pathophysiologic examination of the wounding mechanisms of firearms. J Trauma 1986; 26: $225-35$

9. Uzar Al. Mermi Kinetiği ve Yara Balistiği. Ulusal Cerrrahi Kongre Kitabı. In:Şen D, editör. 15-19 Mayıs. Antalya 2002. S245.

10. Uzar A.I, Güleç B., Kayahan C. ve arkadaşları. Yara Balistiği-I. Kalıcı ve geçici kavite etkileri. Ulusal Travma Dergisi. 1998; 4(4): 235-9.

11. Buket Reel. Matrix Metalloproteinaz Enzimleri ve Ateroskleroz. Türkiye Klinikleri J Med Sci, 2006; 26(5): 527-37.

12. Zeng, Z.S. et al., 1999, Loss of basement: membrane type IV collagen is associated with increased expression of Metalloproteinases 2 and 9 during human colorectal tumorigenesis. Carsinogenesis 20: 749-55.

13. Jhon and Tuszynski G: The role of Matrix Metalloproteinases in tumor angiogenesis and tumor metastasis. Pathol Oncol Res 7: 14-23, 2001.

14. Matsuyama, A. et al., 2003, Matrix Metalloproteinases as novel disease markers in takayasu arteritis, Circulation, 108: 1469-73.

15. Mackay CR, Imhof BA. Cell adhesion in the immune system. Immunol Today.1993; 14(3): 99-102-22.

16. C. S. Elangbam, C. W. Qualls, R. R. Dahlgren. Cell Adhesion Molecules Update. Vet Pathol. 1997; 34, 1:61-73.

17.Jung $\mathrm{U}$, Ley $\mathrm{K}$. Mice lacking two or all three selectins demonstrate overlapping and distinct functions for each selectin. J Immunol. 1999; 162: 6755-62.

18. Tekereci HM, Şahan B, Top C. Hücre adezyon molekülleri. Nobel med. 2008; 4(1): 4-10.

19. Roldan, V. et al. Soluble E-selectin in cardiovascular disease and its risk factors. A review of the literature. Thromb. Haemost. 2003; 90:1007-20. 
20. Peters CE, Sebourn CL. Wound ballistics of unstable projectiles. Part II: temporary cavity formation and tissue damage. J Trauma 1996;40:S16-21.

21. Mesci A, Arıcı C. Travma kinematiği. Ulusal Cerrahi ve Travma Resüsitasyon Kurs Kitabı, 2008.

22. Di Maio VJM. Gunshot Wounds, practical Aspects of Firearms, Ballistics and forensic tecniques. 2nd Ed. CRC Press. LCL, 1999.

23. Kar H. Ateşli Silah Yaralarında Karboksihemoglobin Analizi. Uzmanlık Tezi. Adli Tıp Kurumu. İstanbul, 2002.

24. Mandal M, Mandal A, Das D, Chakraborti T, Sajal C. Clinical implications of matrix metalloproteinases. Mol Cell Biochem, 2003 Oct;252(1-2): 305-29.

25. Visse R, Nagase H. Matrix Metalloproteinases And Tissue İnhibitors Of Metalloproteinases. Structure, Function And Biochemistry. Circ.Res. 2003; 92: 827-39.

26. Muphy G, WillenbrockF, CrabbeT. Regulation Of Matrix Metalloproteinases Activity. Ann Ny. Acad Sci 1994;732:31-41.

27. Cojocarui IM et al. Changes in plasma matrix metalloproteinase-9 levels in patients with acute ischemic stroke. Rom J Intern Med 2012;50:155-8.

28. Eckart RE, Uyehara CFT, Shry EA. Matrix Metalloproteinases In Patients With Myocardial Infarction And Percutaneous Revascularization. J Interven Cardiol 2004;17:27-31.

29. Susskind H, Hymowitz MH, Lau YH, Atkins HL, Hurewitz AN, Valentine ES, et al. Increased plasma levels of matrix metalloproteinase- 9 and tissue inhibitor of metalloproteinase- 1 in lung and breast cancer are altered during chest radiotherapy. Int J Radiat Oncol Biol Phys. 2003;56(4):1161-9.

30. Ferrero-Miliani L, Nielsen OH, Andersen PS, Girardin SE: Chronic inflammation: importance of NOD2 and NALP3 in interleukin-1beta generation. Clin Exp Immunol 2007;147:227-35.

31. Kumar V. Abbas AK. Aster JC. Inflammation and repair. Robbins Basic Pathology (9th edition) Saunders (Elsevier) 2013;43:1781-5.

32. Mackay CR, Imhof BA. Cell adhesion in the immune system. Immunol Today.1993; 14(3): 99-102. 22

33. Paulson JC. Selectin/ carbohydrate- mediated adhesion of leukocytes. In: Harlan JM, Lui DY, eds. Adhesion: Its role in inflamatory disease. New York: WH Freeman, 1992: 104-35.

34. Albelda SM, Smith CW, Ward PA. Adhesion molecules and inflammatory injury. FASEB J 1994; 8: 504囚12.

35. Blankenberg S, Rupprecht HJ, Bickel C, Peetz D, Hafner G, Tiret L, Meyer J. Circulating cell adhesion molecules and death in patients with coronary artery disease, Circulation 2001; 104: 1336-42.

36. Kamijikkoku S, Murohara T, Tayama S, Matsuyama K, Honda T, Ando $M$, Hayasaki K. Acute myocardial infarction and increased soluble intercellular adhesion molecule-1: a marker of vascular inflammation and a risk of early restenosis? Am Heart J 1998; 136: 231-6.

37. Nash MC, Wade O, Shah V, Dillon MJ. Normal levels of soluble E-selectin, soluble intercellular adhesion molecule-1 (sICAM-1), and soluble vascular cell adhesion molecule-1 (sVCAM-1) decrease with age. Clin Exp Immunol 1996; 103: 167ه70.

38. Bevilacqua MP. Endothelial-lukocyte adhesion molecules. Ann Rev of Immunol 1993; 248囚88. 